\title{
PENGARUH LIKUIDITAS PERUSAHAAN DAN PEMBATALAN PERJANJIAN PERDAMAIAN TERHADAP KEPAILITAN PERUSAHAAN
}

\author{
Naomi Adinda Putri Hasan \\ E-mail: naomiadinda@gmail.com \\ Mahasiswa Program S1 Studi IImu Hukum Fakultas Hukum \\ Universitas Sebelas Maret Surakarta \\ Arief Suryono \\ E-mail: ariefsuryono@staff.uns.ac.id \\ Dosen Fakultas Hukum Universitas Sebelas Maret Surakarta
}

\begin{abstract}
This article aims to find out how companies that have good liquidity can be bankrupt and the consequences of canceling Accord and satisfaction based on Law Number 37 of 2004 concerning Bankruptcy and Delaying Obligations of Debt Payments. This normative legal research is prescriptive in that it uses a statutory approach. The types of data used include: secondary data consisting of primary legal materials, secondary legal materials, and tertiary legal materials. Data collection techniques carried out are library research techniques or document studies. Bankruptcy when associated with company liquidity where a company with good liquidity should be able to fulfill its debt obligations, but the bankruptcy of the company is not based on it, but an aspect where when the debtor defaults, the bankruptcy process at the company can be carried out. When default occurs in a accord agreement where there are creditors who request cancellation and are accepted, it automatically results in the bankruptcy of the company, regardless of the financial condition of the company. Bankruptcy also implies that the company is replaced by the Curator to manage the company.
\end{abstract}

Keyword: Bankruptcy; Liquidity; Accord and Satisfaction Agreement

\begin{abstract}
Abstrak
Artikel ini bertujuan untuk mengetahui bagaimana perusahaan yang berlikuiditas baik dapat dipailitkan serta konsekuensi dari pembatalan perjanjian perdamaian berdasarkan Undang-Undang Nomor 37 Tahun 2004 tentang Kepailitan dan Penundaan Kewajiban Pembayaran Utang. Penelitian hukum normative ini bersifat preskriptif yang menggunakan pendekatan perundang-undang. Jenis data yang digunakan antara lain: data sekunder yang terdiri dari bahan hukum primer, bahan hukum sekunder, dan bahan hukum tersier. Teknik pengumpulan data yang dilakukan adalah teknik penelitian kepustakaan atau studi dokumen. Kepailitan jika dikaitkan dengan likuiditas perusahaan dimana perusahaan dengan likuiditas yang baik semestinya mampu memenuhi kewajiban utangnya, akan tetapi pailitnya perusahaan bukan didasarkan pada hal tersebut, melainkan aspek dimana ketika debitur wanprestasi, maka proses kepailitan pada perusahaan dapat dilakukan. Ketika wanprestasi terjadi dalam perjanjian perdamaian dimana ada kreditur yang memohon pembatalannya dan diterima maka secara otomatis berakibat pada pailitnya perusahaan tersebut, terlepas dari keadaan financial perusahaan. Kepailitan juga berimpilkasi pada operasional perusahaan yang selanjutnya digantikan oleh Kurator untuk mengelola perusahaan.
\end{abstract}

Kata Kunci: Kepailitan; Likuiditas; Perjanjian Perdamaian

\section{A. Pendahuluan}

Seiring dengan semakin pesatnya perkembangan zaman, manusia untuk memenuhi kebutuhannya membuat berbagai perusahaan muncul. Untuk menjalankan usahanya suatu perusahaan membutuhkan modal. Modal perusahaan berasal dari pinjaman pihak lain, baik dari perseorangan, perusahaan lain, lembaga keuangan bank, serta lembaga keuangan bukan bank. Pinjaman diperoleh setelah perusahaan (debitur) mengadakan perjanjian utang-piutang dengan pihak lain (kreditur). 
Seringkali pinjaman kepada pihak ketiga tersebut malah menjadi beban tambahan dari perusahaan tersebut mengingat bunga yang melekat pada pinjaman tersebut diiringi dengan kondisi keuangan yang tidak kunjung membaik, sehingga Kreditur juga tidak diberikan kejelasan atas piutang mereka. Hal tersebut merupakan salah satu hal yang melatarbelakangi Undang-Undang Kepailitan sebagai sarana dan instrumen untuk melindungi para kreditur dengan memberikan jalan yang jelas dan pasti untuk menyelesaikan utang yang tidak dapat dibayar. Tanpa adanya utang tersebut maka esensi kepailitan menjadi tidak ada karena kepailitan adalah merupakan pranata hukum untuk melakukan likuidasi asset debitur untuk membayar utang-utangnya kepada para krediturnya. (Hendy Prastyo, 2018:100)

Kepailitan dimulai dengan adanya suatu permohonan pailit terhadap debitur yang memenuhi syarat, "Debitur yang mempunyai dua atau lebih Kreditur dan tidak membayar lunas sedikitnya satu utang yang telah jatuh waktu dan dapat ditagih, dinyatakan pailit dengan putusan pengadilan, baik atas permohonannya sendiri maupun atas permohonan satu atau lebih dari krediturnya." Serta "Permohonan pernyataan pailit harus dikabulkan apabila terdapat fakta atau keadaan yang terbukti secara sederhana bahwa persyaratan untuk dinyatakan pailit sebagaimana dimaksud dalam Pasal 2 ayat (1) telah dipenuhi."

Syarat tersebut mengisyaratkan, suatu permohonan pailit menjadi sangat mudah untuk diajukan terhadap suatu debitur, karena tidak ditentukan oleh syarat lain menyangkut kondisi dan kemampuan debitur untuk memenuhi kewajibannya kepada kreditur. Kemampuan yang dimaksud dilihat dari keuangan, aset-aset dan/atau kekayaan yang dimiliki debitur tersebut.

Namun, untuk menghindari kepailitan debitur dapat melakukan Penundaan Kewajiban Pembayaran Utang (PKPU) dengan mengajukan permohonan perdamaian. Perdamaian tersebut dapat diajukan oleh debitur dalam bentuk Rencana Perdamaian. (Sutan Remy Sjahdeini, 2010: 363)

Perdamaian tersebut berupa perjanjian antara debitur dan para kreditur dimana debitur menawarkan untuk melakukan pembayaran utangnya dengan syarat bahwa ia setelah melakukan pembayaran baik sepenuhnya ataupun sebagian, maka debitur telah melaksanakan perjanjian perdamaian, sehingga debitur tidak mempunyai utang kembali. (Rahayu Hartini, 2008: 175).

Adapun salah satu kasus yang dapat dijadikan rujukan adalah pembatalan perdamaian yang terjadi pada PT Njonja Meneer yang akhirnya menyebabkan perusahaan pailit, meskipun mempunyai likuiditas yang baik, perusahaaan tersebut tetap dinyatakan pailit oleh Pengadilan Niaga. Permohonan pembatalan perdamaian yang diajukan terhadap PT Njonja Meneer kemudian permohonan pembatalan perdamaian tersebut diterima dan dikabulkan oleh Majelis Hakim dalam Putusan Pengadilan Niaga No: 11/ Pdt.Sus-Pailit/2017/PN. Niaga Smg jo. Nomor 01/Pdt.SusPKPU/2015/PN Niaga Smg tentang Pembatalan Perdamaian Terhadap PT Njonja Meneer, akibat hukumnya yaitu PT Njonja Meneer dinyatakan pailit dengan segala akibat hukumnya.

Berdasarkan uraian di atas, maka dalam artikel ini akan membahas tentang keterkaitan likuiditas perusahaan dengan kepailitan serta konsekuensi hukum pembatalan perjanjian perdamaian.

\section{B. Metode Penelitian}

Jenis penelitian yang digunakan merupakan penelitian hukum normatif, yaitu penelitian hukum yang dilakukan dengan cara meneliti bahan pustaka yang ada dengan mendasarkan hukum sebagai suatu norma. Istilah penelitian hukum atau legal research menjelaskan bahwa penelitian tersebut bersifat normatif (Peter Mahmud Marzuki, 2014:55-56).

Sifat penelitian yang digunakan adalah preskriptif. Dalam hal ini bukan hanya sekedar menetapkan aturan yang ada, melainkan juga menciptakan hukum untuk mengatasi masalah yang dihadapi sehingga dapat melakukan penilaian mengenai benar atau salah atau apa yang seyogyanya menurut hukum terhadap fakta atau peristiwa hukum dari hasil penelitian. 
Pendekatan yang digunakan adalah pendekatan perundang-undangan (statue approach) dan pendekatan analitis (analytical approach). Pendekatan perundangan-undangan dilakukan dengan menelaah peraturan perundang-undangan dan regulasi yang cukup mampu menampung permasalahan hukum yang ada, dalam artikel ini juga menggunakan pendekatan analitis untuk mengetahui makna yang dikandung oleh istilah-istilah yang digunakan dalam aturan perundanganundangan secara konsepsional, sekaligus mengetahui penerapannya dalam praktik dan putusanputusan hakim.

Teknik yang dipakai dalam pengumpulan bahan hukum dalam penulisan hukum ini adalah studi dokumen. Studi dokumen ini berguna untuk mendapatkan landasan teori dengan mengkaji dan mempelajari buku-buku, peraturan undang-undang, dokumen laporan, arsipan hasil penelitian lainnya yang berhubungan dengan masalah peneliti. (Peter Mahmud Marzuki, 2014:21) dengan teknik analisa metode silogisme yang menggunakan pola berpikir deduktif. Penggunaan metode deduksi ini berpangkal dari pengajuan premis mayor, kemudian diajukan premis minor. Kemudian dari kedua premis tersebut ditarik suatu kesimpulan, bahwa metode yang lazim digunakan dalam penalaran hukum adalah metode deduksi. (Peter Mahmud Marzuki, 2014: 89).

\section{Hasil Penelitian dan Pembahasan}

1. Kepailitan pada Perusahaan dengan Likuiditas Baik

Undang-Undang Kepailitan tidak mengatur secara khusus ketentuan mengenai kondisi keuangan debitur sebagai syarat dapat dinyatakan pailit. Salah satu acuan dari potensi pailit tersebut dapat dilihat melalui keadaan aktiva dan pasiva keuangannya. Audit Going Concern oleh Auditor merupakan cara yang dapat digunakan untuk mengetahui keadaan keuangan suatu badan usaha atau perseroan. Untuk mengetahui sejauh mana kemampuan debitur untuk memenuhi kewajibannya. Perusahaan yang berada pada proses permohonan pailit banyak ditemukan di dalamnya berbagai macam indikator terkait dengan masalah kelangsungan usaha (going concern). Salah satu indikator tersebut adalah masalah keuangan perusahaan. Indikator yang berkaitan dengan keadaan tersebut menggambarkan tingkat kesehatan perseroan yang dapat memberikan indikasi apakah perseroan dalam kondisi baik atau tidak. Perusahaan yang baik akan mempunyai profitabilitas yang besar dan cenderung memiliki laporan keuangan yang sewajarnya, sehingga potensi untuk mendapatkan opini yang baik dari auditor sebagai profesional yang mengaudit keuangan perusahaan.

Jika dikaitkan dengan Hukum Kepailitan di Indonesia seperti yang Sutan Remy Sjahdeini nyatakan dalam bukunya bahwa menurut Pasal 1 ayat (1) Undang-Undang Kepailitan, terhadap seorang debitur dapat diajukan permohonan pernyataan pailit hanya apabila debitur telah berhenti membayar utang-utangnya. Keadaan berhenti membayar haruslah merupakan keadaan yang objektif, yaitu karena keadaan keuangan debitur telah mengalami ketidakmampuan (telah dalam keadaan tidak mampu) membayar utang-utangnya. (Sutan Remy Sjahdeini, 2010:39)

Debitur tidak boleh sekedar tidak mau membayar utang-utangnya (not willing to repay his debts), tetapi keadaan objektif keuangan kantor akuntan publik yang dalam keadaan tidak mampu membayar utang-utangnya (not able to repay his debts), untuk menentukan apakah keadaan keuangannya dalam keadaan debitur sudah dalam keadaan tidak mampu membayar utang-utangnya, atau dengan kata lain debitur telah dalam keadaan insolven, harus dapat ditentukan secara objektif dan independen. Hal itu hanya dapat dilakukan berdasarkan financial audit atau financial due dilligent yang dilakukan oleh suatu kantor akuntan publik yang independen." (Sutan Remy Sjahdeini, 2010: 39)

Setiap rasio keuangan memiliki tujuan kegunaan dan arti tertentu. Setiap hasil dari rasio yang diukur dan diinterpretasikan sehingga menjadi berarti bagi pengambilan keputusan.(Kasmir, 2010: 66-67). Secara umum rasio keuangan yang sering digunakan untuk menilai kinerja keuangan perusahaan adalah rasio likuiditas, rasio profitabilitas atau rasio yang menunjukkan 
dari suatu perusahaan dalam menghasilkan keuntungan (profit), rasio aktivitas merupakan rasio yang menyatakan kemampuan suatu perusahaan dalam memanfaatkan sumber daya yang dimiliki serta bagaimana perusahaan dalam mengelola aset yang dimilikinya. Rasio solvabilitas (leverage), menunjukkan kemampuan perusahaan dalam memenuhi kewajiban jangka panjang. Rasio pasar, rasio yang menunjukkan informasi penting perusahaan dan diungkapkan dalam basis per saham. Rasio likuiditas merupakan suatu indikator mengenai kemampuan perusahaan dalam membayar semua kewajiban finansial jangka pendek pada saat jatuh tempo dengan menggunakan aset lancar yang tersedia. Sehingga dalam laporan keuangan akan dapat dihitung sejumlah rasio keuangan yang wajar dijadikan sebagai dasar penilaian terhadap kinerja suatu peusahaan. (Emi Agustin, "Analisis Rasio Keuangan Untuk menilai kinerja keuangan PT Indo Farma Tbk berdasarkan KEP-100/MBU/2002", eJournal Imu Administrasi Bisnis, Vol. 4, No. 1, 2016.)

Permasalahan yang sering terjadi akibat dari tidak terpenuhinya kewajiban perusahaan adalah gugatan wanprestasi yang diajukan oleh kreditur pada pengadilan.

Wanprestasi merupakan suatu sikap dimana seseorang tidak memenuhi atau lalai melaksanakan kewajiban sebagaimana yang telah ditentukan dalam perjanjian yang dibuat antara kreditur dan debitur. (Abdul R Saliman, 2014:15). Prof. Subekti, menyebutkan wanprestasi dapat berbentuk:

1. Tidak melakukan apa yang disanggupi untuk dilakukan;

2. Melakukan apa yang diperjanjikan tapi tidak sebagaimana yang diperjanjikan;

3. Melakukan sesuatu yang oleh perjanjian tidak boleh dilakukan;

4. Melakukan apa yang sudah diperjanjikan tapi terlambat.

Dari pengertian tersebut, kewajiban pembayaran utang kepada kreditur dapat dikategorikan dalam bentuk wanprestasi apabila tidak sesuai dengan yang diperjanjikan. Adanya UndangUndang Kepailitan, perihal sengketa utang-piutang diselesaikan melalui Pengadilan Niaga memberikan penyelesaian yang menguntungkan bagi kedua belah pihak. Serta adanya proses PKPU tersebut memberikan jaminan kepastian hukum kepada kreditur atas utangutang debitur. Di sisi lain, PKPU juga menguntungkan debitur dalam hal, perpanjangan waktu pembayaraan utang kasus yang menimpa PT Njonja Meneer, dimana PT Njonja Meneer dinyatakan pailit oleh Pengadilan Negeri Semarang, karena dianggap melanggar kesepakatan damai yang tertuang dalam proposal perdamaian dalam sidaang PKPU. PT Njonja Meneer dianggap lalai karena tidak memenuhi kewajibannya dalam hal pembayaran utang kepada kreditur yang bernama Hendrianto Bambang Santoso.

Putusan Pengadilan Negeri Semarang No: 11/ Pdt.Sus-Pailit/2017/PN. Niaga Smg jo. Nomor 01/Pdt.Sus-PKPU/2015/PN Niaga Smg tentang Pembatalan Perdamaian terhadap PT Njonja Meneer, menyatakan batal Perjanjian Perdamaian yang telah disahkan oleh Majelis Hakim Pengadilan Niaga pada Pengadilan Negeri Semarang yang dituangkan dalam Putusan Pengesahan Perdamaian (Homologasi) Nomor 01/Pdt.Sus-PKPU/2015/PN Niaga Smg tanggal 08 Juni 2015 dan PT Njonja Meneer dinyatakaan pailit dengan segala akibat hukumnya yang seharusnya sudah jatuh tempo.

Permohonan pembatalan perdamaian yang diajukan oleh kreditur dikabulkan, karena adanya ingkar janji atau cidera janji yang dilakukan oleh PT Njonja Meneer terhadap krediturkrediturnya. Ingkar janji berupa tidak terpenuhinya kewajiban pembayaran utang kepada kreditur, karena kelalaiannya dalam memberikan 10 lembar cek, namun kesemuanya tidak dapat dicairkan dengan alasan rekening telah ditutup. Selain itu, PT Njonja Meneer juga memberikan bilyet giro kepada kreditur, namun sebagian dari bilyet tersebut tidak dapat dicairkan karena saldo tidak mencukupi.

Jika dikaitkan dengan likuiditas perusahaan dimana perusahaan dengan likuiditas yang baik mampu memenuhi kewajiban utangnya, namun dalam kasus PT Njonja Meneer, pernyataan pailit lebih pada akibat dari ingkar janji/wanprestasi dari perdamaian bukan dari 
kemampuan memenuhi kewajiban pada pihak ketiga. Sehingga dapat dikatakan likuiditas yang baik tidak menjamin tidak dapat dilakukannya proses kepailitan terhadap perusahaan, terlebih setelah adanya perjanjian perdamaian yang telah mendapatkan pengesahaan.

Sehingga kepailitan dapat dilakukan tidak hanya karena tidak mampunya debitur dalam hal memenuhi kewajibannya, melainkan juga pada aspek perjanjian dimana ketika debitur ingkar janji/cidera janji/wanprestasi, maka proses permohonan kepailitan pada perusahaan dapat dilakukan.

2. Akibat Hukum dari Perjanjian Perdamian yang Dibatalkan

Terdapat dua jenis perjanjian perdamaian yaitu perjanjian perdamaian yang ditawarkan dalam rangka PKPU dan perjanjian perdamaian dalam rangka kepailitan. yang ditawarkan kepada para kreditur setelah debitur dinyatakan pailit oleh Pengadilan Niaga.

Perdamaian pada PKPU berbeda dengan perdamaian dalam kepailitan. Perbedaan perdamaian antara perdamaian pada PKPU dan perdamaian pada kepailitan dapat dilihat dari segi waktu, penyelesaian, syarat penerimaan, dan kekuatan mengikat.

Tujuan utama dari permohonan PKPU adalah untuk merestrukturisasi utang, bukan untuk likuidasi. Dalam mengajukan permohonan PKPU, debitur memohon agar diberi waktu yang cukup memadai untuk membayar utang-utangnya dengan melampirkan atau diikuti dengan rencana perdamaian (compotition plan). Rencana perdamaian pada pokoknya antara lain berisi restrukturisasi utang, penjadwalan ulang (rescheduling) utang, pemotongan bunga, denda dan biaya-biaya lainnya serta restrukturisasi perusahaan apabila yang memohon PKPU adalah perusahaan.

Perdamaian ini memang tidak dapat menghindarkan kepailitan, karena kepailitan itu sudah terjadi, akan tetapi apabila perdamaian itu tercapai maka kepailitan debitur yang telah diputus oleh pengadilan itu menjadi berakhir. perdamaian atau accord dalam kepailitan dan PKPU bersifat voluntary, accord dapat diajukan secara sukarela oleh debitur pailit manakala debitur pailit merasa masih mampu untuk memenuhi kewajiban-kewajibannya kepada para kreditur (dalam keadaan solven).

Adanya accord inilah yang memberikan pemikiran kepada para pembuat Undang-Undang Kepailitan untuk meniadakan insolvency test, tes insolvensi (insolvency test) merupakan suatu metode yang dilakukan untuk menentukan tingkat kesehatan usaha debitur, guna mengukur kemampuan debitur membayar utang-utangnya yang nantinya akan dijadikan suatu ukuran apakah debitur layak untuk dipailitkan atau tidak. Oleh karena itu, manakala debitur pailit merasa masih mampu dan menghitung adanya peluang untuk tetap bertahan selanjutnya akan menggunakan accord sebagai upaya untuk mengakhiri kepailitan. Mungkin pula dalam keadaan yang sebaliknya yaitu debitur tersebut sedang berada dalam kesulitan membayar dan sampai saat ini pelaksanaan untuk pengaturan pembayaran dibantu oleh pendukung keuangan para anggota keluarga dan relasi. Hal ini jelas memberikan titik cerah bagi kreditur untuk mendapatkan hasil yang lebih besar daripada dilakukan pemberesan harta pailit.

Perjanjian perdamaian dalam sidang penundaan kewjiban pembayaran utang (PKPU) dapat dikatakan lebih menguntungkan kepada debitur. Hal tersebut dapat dilihat dari ketentuan dalam pasal 286 Undang-Undang Kepailitan yang menyatakan: "Perdamaian yang telah disahkan, mengikat semua kreditur, kecuali Kreditur yang tidak menyetujui rencana perdamaian sebagaimana dimaksud dalam Pasal 281 ayat (2)"

Ketentuan tersebut mengharuskan semua kreditur menyetujui/sepakat dengan perjanjian perdamaian yang dibuat oleh debitur. Dengan kata lain, kreditur yang tidak sepakat dengan perjanjian perdamaian tersebut harus rela sepakat dengan perjanjian tersebut.

Perjanjian perdamaian dapat dibatalkan dalam hal yang disebabkan oleh karena pihak Debitur telah lalai dalam melaksanakan perdamaian tersebut. Hal ini berlaku asas pembuktian terbalik, yakni pihak Debitur yang harus membuktikan bahwa perdamaian tersebut telah dipenuhinya. 
Namun seperti yang diatur dalam pasal 291 ayat (2) Undang-Undang Kepailitan menyatakan bahwa "Dalam putusan Pengadilan yang membatalkan perdamaian, Debitur juga harus dinyatakan pailit". Jadi akibat hukum dari proses pembatalan perjanjian perdamaian adalah debitur dinyatakan pailit. Dengan kata lain, ketika perjanjian perdamaian dalam yang dibatalkan maka secara otomatis berakibat pada pailitnya perusahaan tersebut, meskipun perusahaan tersebut secara financial mempunyai likuiditas yang baik.

Konsekuensi kepailitan juga berimpilkasi pada operasional perusahaan dimana selanjutnya dilakukan oleh Kurator yang bertugas sebagai pengelola perusahaan. Kurator dapat diajukan oleh kreditur atas persetujuan hakim dalam sidang kepailitan. Kurator dalam menjalankan tugasnyanya diawasi oleh hakim pengawas yang ditunjuk oleh majelis hakim.

\section{Simpulan}

1. Perusahaan yang likuiditasnya baik dapat dipailitkan, sebab berdasarkan Pasal 8 ayat 4 UndangUndang Kepailitan, pailitnya suatu perusahaan atau debitur lebih pada akibat ketidakmauan debitur memenuhi prestasinya, bukan dari ketidakmampuannya dalam memenuhi kewajiban pada pihak kreditur. Sehingga dapat dikatakan likuiditas yang baik tidak menjamin dapat tidaknya dilakukan proses kepailitan terhadap perusahaan.

2. Konsekuensi perjanjian perdamaian yang dibatalkan adalah secara otomatis berakibat pada pailitnya debitur, meskipun debitur atau perusahaan tersebut secara financial mempunyai likuiditas yang baik. Konsekuensi kepailitan berimpilkasi pada oprasional perusahaan dimana selanjutnya dilakukan oleh kurator yang bertugas sebagai pengelola harta benda debitur.

\section{E. Saran}

1. Undang-Undang Kepailitan di masa datang dapat lebih melindungi kepentingan debitur, seyogyanya disusun dengan tujuan menghidupkan dan menyegarkan kembali dunia usaha atau setidaknya tidak membiarkan perusahaan mati, karena yang berkepentingan terhadap perusahaan bukan saja debitur atau kreditur, tetapi juga masyarakat konsumen, masyarakat pencari kerja dan yang bekerja serta pemerintah terutama berkaitan dengan pendapatan pajak dari perusahaan yang sehat. Serta tidak membiarkan dirinya dipergunakan oleh kreditur dan pihak-pihak lainnya yang berkepentingan dengan boedel pailit, sehingga dengan mudah mempailitkan perusahaan yang sebenarnya sehat.

2. Bagi pembuat Undang-Undang, yaitu DPR dan Pemerintah hendaknya melakukan revisi Undang-Undang Kepailitan guna melindungi kepentingan debitur dengan memberikan perpanjangan jangka waktu dalam proses PKPU. Sehingga pada saat pelaksanaan perjanjian perdamaian, debitur dapat melaksanakannya secara optimal.

\section{F. Daftar Pustaka}

\section{Buku}

Adul R Saliman. 2014. Hukum Bisnis Untuk Perusahaan, Edisi 4. Jakarta: Kencana Prenada Media Group.

Kasmir. 2010. Pengantar Manajemen Keuangan. Jakarta: Kencana.

Peter Mahmud Marzuki. 2014. Penelitian Hukum, Edisi Revisi. Jakarta: Kencana Prenada Media Group. Rahayu Hartini. 2008. Hukum Kepailitan. Malang: UMM Press.

Sutan Remy Sjahdeini. 2010. Hukum Kepailitan: Memahami Undang-Undang No.37 Tahun 2004 Tentang Kepailitan. Jakarta: Pustaka Utama Grafiti. 
Jurnal

Emi Agustina. 2016. "Analisis Rasio Keuangan Untuk menilai kinerja keuangan PT Indofarma Tbk berdasarkan KEP-100/MBU/2002" eJournal IImu Administrasi Bisnis. Vol. 4, No. 1, 2016. Samarinda: Fakultas IImu Sosial dan IImu Politik Universitas Mulawarman.

Evie Sompie. 2014."Akibat Hukum Putusan Pengadilan Niaga terhadap Debitur yang Dinyatakan Pailit Berdasarkan Undang-Undang Nomor 37 Tahun 2004". Lex Privatum. Vol.II/No. 2/April/2014. Manado: Fakultas Hukum Universitas Sam Ratulangi.

Hendy Prastyo. 2017. "Akibat Hukum Terhadap Akta yang Dibuat Oleh Atau Dihadapan Notaris Setelah Dinyatakan Pailit”. Journal Repertorium. Vol 5, No 2 (2018). Surakarta: Program Magister Kenotariatan Fakultas Hukum Universitas Sebelas Maret.

Melissa Olivia Tanor dan Harijanto Sabijono \& Stanley Kho Walandouw. 2015. "Analisis Laporan Keuangan dalam Mengukur Kinerja Keuangan pada PT. Bank Artha Graha Internasional, Tbk". Jurnal Emba. 639. Vol.3 No.3 Sept.2015. Manado: Fakultas Ekonomi dan Bisnis Universitas Sam Ratulangi.

Samuel Yau Man Zeto. 2016. "Asset liquidity and stock returns". Journal of Advances in Accounting, incorporating Advances in International Accounting. Vol.35. Kowloon Tong: Department of Finance and Decision Sciences Hong Kong Baptist University. Peraturan Perundang-undangan

Undang-Undang Republik Indonesia Nomor 21 Tahun 2011 tentang Otoritas Jasa Keuangan

Undang-Undang Nomor 37 Tahun 2004 tentang Kepailitan dan Penundaan Kewajiban Pembayaran Utang.

Kitab Undang-Undang Hukum Perdata 